\title{
ANALISIS TIOSIANAT DALAM URIN SEBAGAI METODE MONITORING POTENSI GAKI (GANGGUAN AKIBAT KEKURANGAN IODIUM) BERBASIS TEST KIT
}

\author{
(ANALYSIS OFTHIOCYANATE ON URINE AS MONITORING METHOD OF \\ POTENTIAL GAKI (IODINE DEFICIENCY DISORDERS) BASED ON TEST KIT)
}

\author{
Yulia Dwi Cahyani, Mike Nur Izzati, M. Dzulfahmi Ramadhan, Jamilah, \\ Nur Rahmah Fadilah Shaumi, Hermin Sulistyarti
}

\author{
Fakultas Matematika dan Ilmu Pengetahuan Alam Universitas Brawijaya \\ Jl. Veteran 1, Malang 65145 telp. (0341) 575838 \\ e-mail: $\underline{\text { hermin@ub.ac.id }}$
}

\begin{abstract}
Abstrak
Tujuan penelitian ini adalah menganalisis tiosianat dalam urin berbasis tes kit. Pada penelitian ini tiosianat dioksidasi oleh hipoklorit menjadi sianida yang selanjutnya bereaksi dengan ninhidrin membentuk senyawa hidrindantin. Hidrindantin yang dihasilkan berwarna merah dengan intensitas yang proporsional terhadap konsentrasi tiosianat yang ada. Semakin besar konsentrasi tiosianat, maka intensitas warna semakin tinggi. Kondisi optimum pembentukan hidrindantin meliputi $\mathrm{pH}$, konsentrasi hipoklorit, dan waktu kestabilan kompleks diteliti melalui metode spektrofotometri pada panjang gelombang 489,50nm. Kondisi optimum pembentukan hidrindantin merah adalah pada $\mathrm{pH} 10$, konsentrasi hipoklorit $0,05 \mathrm{M}$, dan waktu kestabilan senyawa hidrindatin merah adalah 15 menit. Hasil penelitian menunjukkan bahwa test kit yang dihasilkan dapat mendeteksi tiosianat dengan konsentrasi 1-10 ppm. Metode ini divalidasi dengan mengaplikasikan test kit pada sampel sintetis dan urin serta membandingkan hasilnya dengan metode standar spektrofotometri berbasis pembentukan kompleks $\mathrm{Fe}(\mathrm{SCN})^{2+}$.
\end{abstract}

Kata kunci: hidrindantin merah, ninhidrin, optimasi, test kit, tiosianat

\begin{abstract}
The aim of the researh is to analyse of thiocyanate on urine. In this research, thiocyanate is oxidized by hypochlorite to cyanide that can react with ninhydrin to form a red complex compound called hydrindantin. The color intensity of red hydrindantin is proprotional to thiocyanate concentration. The higher thiocyanate concentration then the higher color intensity is. The optimum condition to form hydrindantin, such as $\mathrm{pH}$, concentration of hypochlorite, and time stability of hydrindantin formation was studied using spectrophotometry at maximum wavelength of 489.50nm. The optimum condition for hydrindantin complex were $\mathrm{pH}$ of 10, concentration of hypochlorite of $0.05 \mathrm{M}$, and the time stability of hydrindatin is 15 minutes. The proposed test kit can be used to determine thiocyanate concentration at range of 1-10ppm. The test kit has been applied to synthetic sample and urine, also compared the result to those obtained from standard spectrophotometric method to based formation of complex $\mathrm{Fe}(\mathrm{SCN}) 2+$.
\end{abstract}

Keywords: hydrindantin, ninhydrin, optimization, test kit, thiocyanate 
Jurnal Penelitian Saintek, Vol. 20, Nomor 1, April 2015

\section{PENDAHULUAN}

Gangguan Akibat Kekurangan Iodium (GAKI) merupakan gangguan kesehatan yang disebabkan oleh terganggunya sintesis hormon tiroid. Akibat dari GAKI sendiri dalam tahap awal akan menyebabkan pembengkakan kelenjar tiroid (gondok) dan pada tahap yang lebih serius dapat menyebabkan terhambatnya pertumbuhan fisik, terganggunya sistem saraf, keter-belakangan mental, tuli dan kebutaan. Salah satu penyebab terganggunya sintesis hormon tiroid adalah adanya senyawa tiosianat dalam tubuh (Lubis, 2013).

Tiosianat merupakan zat goitrogenik yang apabila masuk ke dalam tubuh akan bersaing dengan iodium dalam proses sintesis hormon tiroid (trapping) sehingga dapat menghambat penyerapan iodium (Lubis, 2013). Hal ini disebabkan karena adanya tiosianat dalam tubuh dapat menghambat transpor aktif iodium dalam kelenjar tiroid mengakibatkan hampir semua zat iodium yang masuk ke dalam tubuh melalui makanan akhirnya dibuang melalui urin (A'yuni, 2012). Pada manusia dan hewan, tiosianat dapat diperoleh dalam serum, urin, keringat, liur, dan air mata (Putnam, 1971). Namun, ekskresi tiosianat terbesar dilakukan oleh ginjal, sehingga analisis tiosianat dilakukan dengan mengukur kadarnya di dalam urin, dimana batas normal kadar tiosianat dalam tubuh adalah $2 \mathrm{ppm}$ (Sartini, 2012).

Analisis tiosianat pada umumnya dilakukan menggunakan metode potensio- metri dan metode argentometri. Selain itu, metode lain yang dapat dilakukan untuk analisis tiosianat adalah metode test kit. Metode test kit merupakan metode yang didasarkan pada metode kolorimetri. Metode inididasarkan pada pembentukan warnadengan intensitas yang berbeda dengan konsentrasi komponen yang berbeda. Metode ini mengacu pada metode konvensional argentometri, dengan adanya reaksi pengendapan dan menggunakan $\mathrm{Fe}^{3+}$ sebagai indikator (Lubis, 2013). Analisis tiosianat juga telah dilaporkan berdasarkan oksidasi tiosianat oleh permanganat menjadi sianida yang kemudian bereaksi dengan nikel beramoniak membentuk kompleks nikel terasianonikelat (Sulistyarti et al., 2010). Analisis sianida juga dapat dilakukan berdasarkan pembentuk an kompleks hidrin-dantin antara sianida dengan ninhidrin. Hidrindantin dapat membentuk 2-siano-1,2,3-trihidroksi-2hidrindatin dengan siani-da yang lain (Mihaescu, 2010). Reaksi pembentukan hidrindantin ditunjukkan pada Gambar 1.

Pada pembentukan kompleks hidrindantin, tiosianat dioksidasi oleh natrium hipoklorit menjadi sianida kemudian terkomplekskan dengan ninhidrin sehingga terbentuk kompleks hidrindantin. Dalam reaksi ini konsentrasi natrium hipoklorit yang digunakan akan mempengaruhi proses oksidasi tiosianat. Kompleks hidrindantin sendiri memiliki dua warna, yaitu merah pada $\mathrm{pH}$ 8-12 dan biru pada $\mathrm{pH}$ 12-12,8 


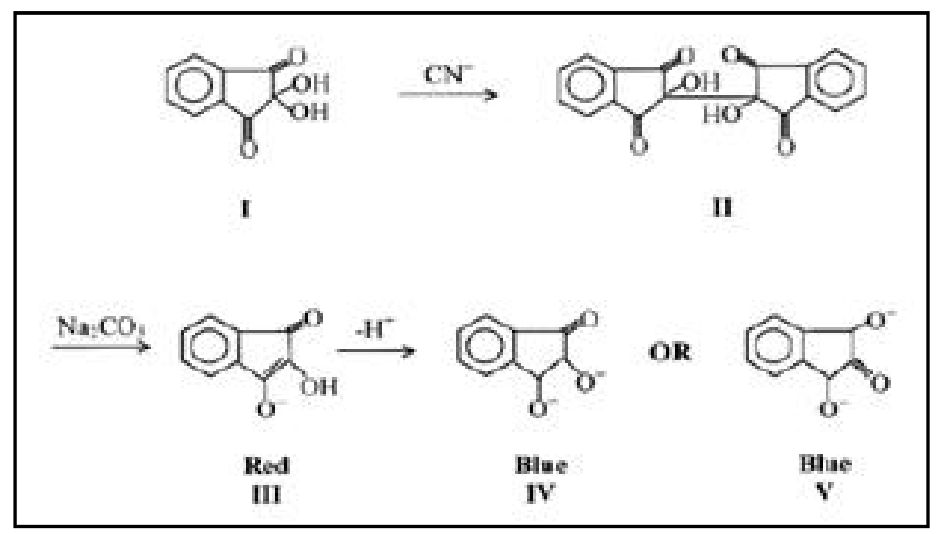

Gambar 1. Reaksi Pembentukan Kompleks Hidrindantin (Nagaraja et al., 2002)

(Nagaraja, et al., 2002). Kompleks yang dihasilkan memiliki waktu kestabilan tertentu pula, dimana pada rentang waktu tertentu warna dari kompleks akan mulai memudar. Pada penelitian ini dilakukan optimasi konsentrasi oksidator yaitu natrium hipoklorit, $\mathrm{pH}$ pembentukan kompleks, dan waktu kestabilan kompleks.

\section{METODE PENELITIAN}

Bahan-bahan yang digunakan dalam penelitian ini baik untuk pembuatan test kit, maupun pengujian, dan validasi secara spektrofotometri adalah $\mathrm{NH}_{4} \mathrm{SCN}$, ninhidrin, $\mathrm{Na}_{2} \mathrm{CO}_{3}, \mathrm{NaOCl}, \mathrm{NaOH}, \mathrm{Fe}\left(\mathrm{NO}_{3}\right)_{3} \cdot 9 \mathrm{H}_{2} \mathrm{O}$, $\mathrm{HNO}_{3}$ pekat, aquadem dan sampel urine.

Prosedur yang dilakukan meliputi preparasi larutan, pembentukan kompleks hidrindantin, penentuan panjang gelombang maksimum menggunakan metode spektrofotometri pada rentang panjang gelombang 400-700 nm, optimasi $\mathrm{pH}$ pembentukan kompleks hidrindantin pada rentang 7-12, optimasi waktu kestabilan kompleks dengan rentang 0-50 menit, optimasi konsentrasi natrium hipoklorit sebagai oksidator dengan variasi konsentrasi $0,01 \mathrm{M} ; 0,05 \mathrm{M} ; 0,10 \mathrm{M}$; 0,15 M; dan 0,20 M, pembuatan komparator warna, serta validasi test kit tiosianat dengan metode standar spektrofotometri berdasarkan pembentukan kompleks $\mathrm{Fe}(\mathrm{SCN})^{2+}$ yang diawali dengan pembuatan kurva baku $\mathrm{Fe}(\mathrm{SCN})^{2+}$ yang dilanjutkan dengan pengukuran sampel yang mengandung tiosianat namun belum diketahui konsentrasinya, sampel yang sama diukur konsentrasinya dengan metode testkit pula, kemudian hasil dari keduanya dibandingkan.

\section{HASIL DAN PEMBAHASAN}

Berdasarkan penelitian yang telah dilakukan, diketahui bahwa kompleks hidrindantin dapat terbentuk dengan mereaksikan $1 \mathrm{~mL} \mathrm{NH}_{4} \mathrm{SCN}$ dengan 0,15 $\mathrm{mL} \mathrm{Na}_{2} \mathrm{CO}_{3} 0,5 \%$, kemudian ditambahkan $1 \mathrm{~mL}$ ninhidrin $1 \%$, dan $0,15 \mathrm{~mL} \mathrm{NaOCl}$, selanjutnya $\mathrm{pH}$ larutan dikondisikan dengan $\mathrm{NaOH} 1 \mathrm{M}$ pada $\mathrm{pH} 10$ kemudian larutan didiamkan selama 15 menit. Kompleks hidrindantin yang dihasilkan berwarna 
merah. Reagen $\mathrm{Na}_{2} \mathrm{CO}_{3}$ berfungsi sebagai larutan buffer yang menstabilkan $\mathrm{pH}$ sianida hasil oksidasi dari tiosianat dan warna merah hidrindantin. Ninhidrin berfungsi sebagai reagen pengompleks sianida yang terbentuk dari hasil oksidasi tiosianat. $\mathrm{NaOCl}$ berfungsi sebagai oksidator untuk merubah tiosianat menjadi sianida sehingga dapat direaksikan secara selektif untuk membentuk kompleks hidrindantin, sedangkan $\mathrm{NaOH}$ berfungsi sebagai reagen untuk mengkondisikan $\mathrm{pH}$ pembentukan kompleks hidrindantin, karena kompleks hidrindantin memiliki perbedaan warna pada rentang $\mathrm{pH}$ tertentu. Kompleks hidrindantin yang diperoleh ditentukan panjang gelombang maksimumnya menggunakan metode spektrofotometri pada rentang panjang gelombang 400-700 nm dengan instrumentasi Spektrofotometer UV-Vis 1601/Shimadzu, sehingga diperoleh spektra pada Gambar 2.

Berdasarkan spektra pada Gambar 2, diketahui bahwa panjang gelombang maksimum untuk kompleks hidrindantin merah adalah 489,5 nm. Hal ini sesuai dengan teori, dimana Nagaraja et al. (2002) menyatakan bahwa panjang gelombang dari kompleks hidrindantin merah adalah $490 \mathrm{~nm}$. Panjang gelombang maksimum tersebut selanjutnya digunakan sebagai panjang gelombang pada optimasi $\mathrm{pH}$ pembentukan kompleks, waktu kestabilan kompleks dan konsentrasi oksidator natrium hipoklorit. Kompleks hidrindantin merah dapat ter-bentuk pada $\mathrm{pH}$ 8-12 sehingga dilakukan optimasi $\mathrm{pH}$ pada rentang 7-12 dengan interval 1 , dimana $\mathrm{pH}$ dikondisikan de-ngan menggunakan $\mathrm{NaOH} 1 \mathrm{M}$ kemudian didiamkan selama 15 menit. Kompleks hidrindantin yang dihasilkan selanjutnya diukur absorbansinya menggunakan instrumentasi Spektrofotometer UV-Vis 1601/ Shimadzu, sehingga diperoleh kurva pada Gambar 3, dan diketahui bahwa pH optimum pembentukan kompleks hidrindantin adalah 10. Pada pH 10, kompleks hidrindantin lebih stabil dibandingkan dengan $\mathrm{pH}$ lainnya karena di atas $\mathrm{pH} 10$, kompleks hidrindantin mulai terdekomposisi.

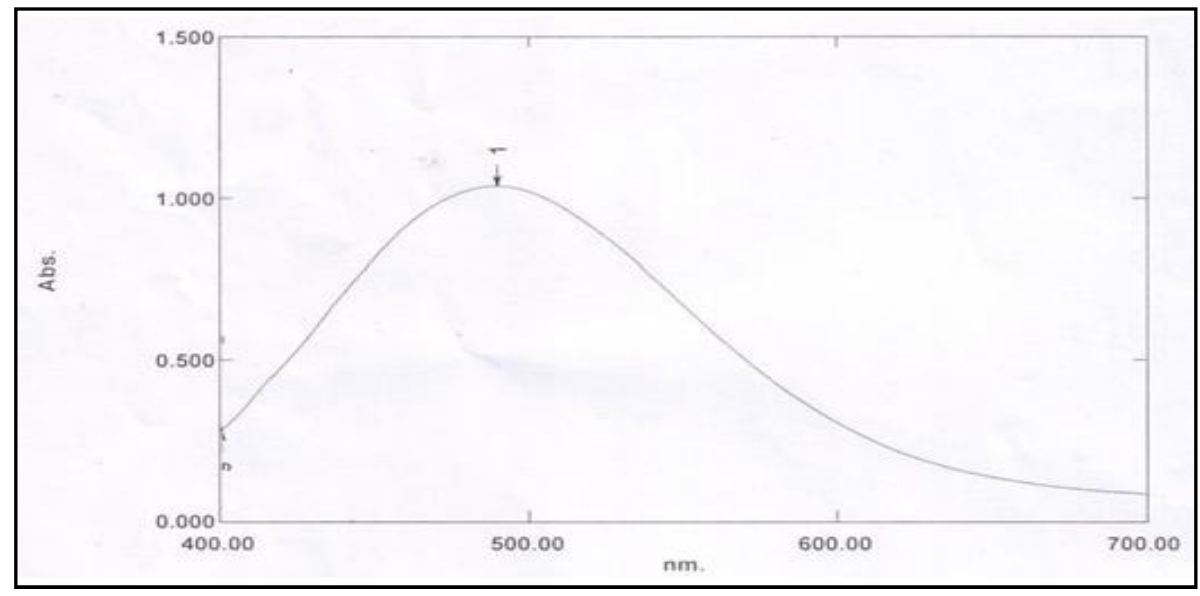

Gambar 2. Spektra Penentuan Panjang Gelombang Maksimum Kompleks Hidrindantin 


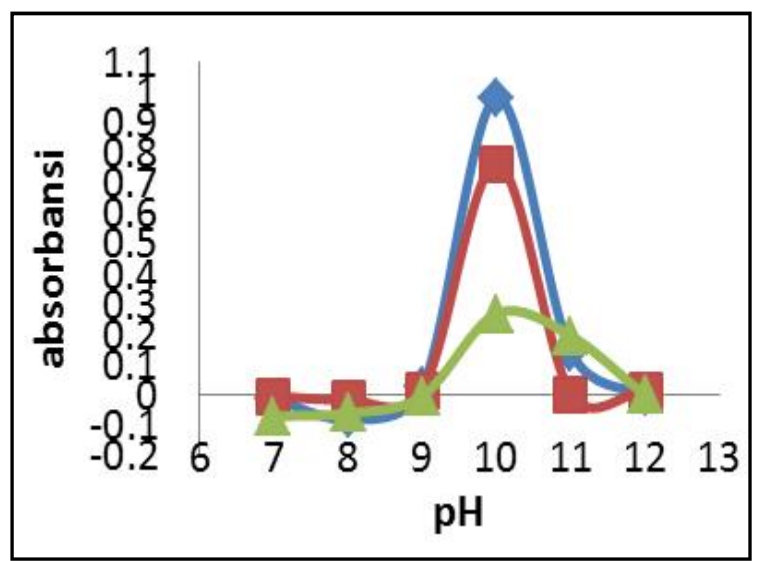

Gambar 3. Kurva Hubungan $\mathrm{pH}$ Pembentukan Kompleks dengan Absorbansi

Setelah diketahui kodisi $\mathrm{pH}$ optimum dari pembentukan hidrindatin selanjutnya digunakan pada penentuan waktu kestabilan senyawa hidrindantin. Waktu kestabilan diketahui berdasarkan metode spektrofotometri pada panjang gelombang 489,5nm dengan memvariasi lama waktu pendiaman kompleks hidrindantin dari 0-50 menit dengan interval 2 menit. Berdasarkan pengukuran yang telah dilakukan diperoleh kurva pada Gambar 4. Dari kurva tersebut

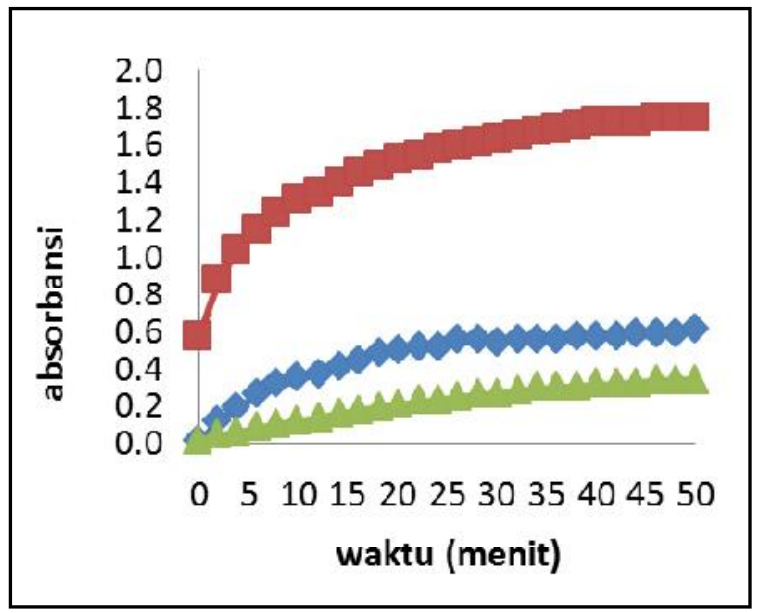

Gambar 4. Kurva Hubungan Waktu Pendiaman dan Absorbansi Hidrindatin dengan variasi konsentrasi $\mathrm{NH}_{4} \mathrm{SCN}$ yang berbeda menghasilkan profil kurva yang sama, dan diketahui bahwa absorbansi terus meningkat, namun berdasarkan uji $\mathrm{T}$ diketahui bahwa waktu kestabilan kompleks adalah 15 menit.

Setelah diketahui kondisi pH optimum dan waktu kestabilan kompleks, dilakukan penentuan konsentrasi optimum oksidator natrium hipoklorit yang digunakan dengan melakukan variasi konsentrasi 0,01 M; 0,05 M; 0,10 M; 0,15 M; dan 0,20 M. Optimasi dilakukan pada kondisi optimum pembentukan kompleks hidrindantin kemudian diukur absorbansinya dengan metode spektrofotometri pada panjang gelombang 489,5 nm. Sehingga, diperoleh kurvahubungan konsentrasi oksidator dan absorbansi pada Gambar 5. Berdasarkan pengukuran diketahui bahwa oksidator natrium hipoklorit dengan konsentrasi 0,05 $\mathrm{M}$ menghasilkan absorbansi optimum.

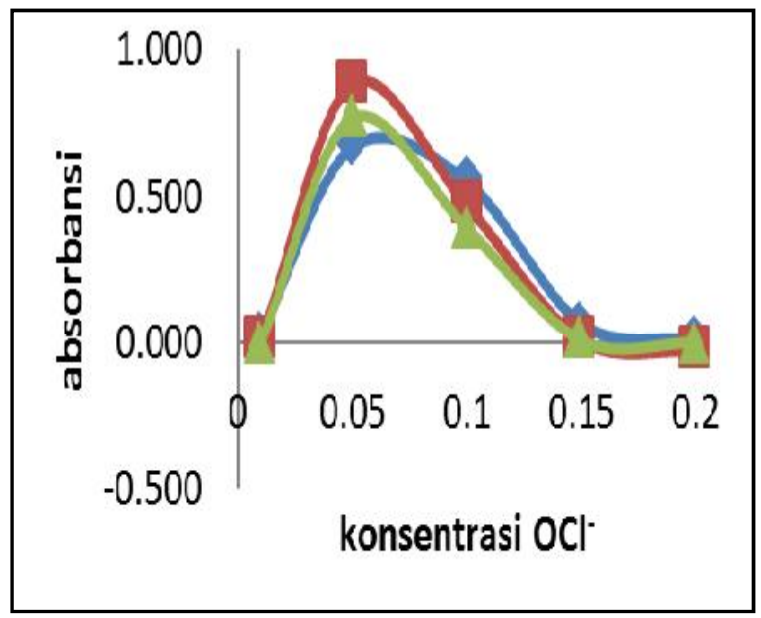

Gambar 5. Kurva Hubungan antara Konsentrasi $\mathrm{NaOCl}$ 
Setelah diketahui kondisi optimum dari pembentukan kompleks hidrindantin, dibuat komparator warna daritest kit tiosianat dengan mereaksikan reagen $\mathrm{Na}_{2} \mathrm{CO}_{3} 0,5 \%$, ninhidrin $1 \%, \mathrm{NaOCl} 0,5 \mathrm{M}, \mathrm{NaOH} 0,5 \mathrm{M}$ dengan beberapa variasi konsentrasi NH4SCN yang digunakan. Test kit yang dihasilkan mampu membedakan tiosianat pada kisaran konsentrasi 1-10 ppm dengan interval 1ppm. Warna dari kompleks hidrindantin semakin pekat dengan semakin tingginya konsentrasi tiosianat yang terdapat dalam sampel. Selanjutnya, akan dibuat komparator warna sebagai alat pendeteksi konsentrasi tiosianat berdasarkan warna. Komparator warna yang dihasilkan ditunjukkan pada Gambar 6.

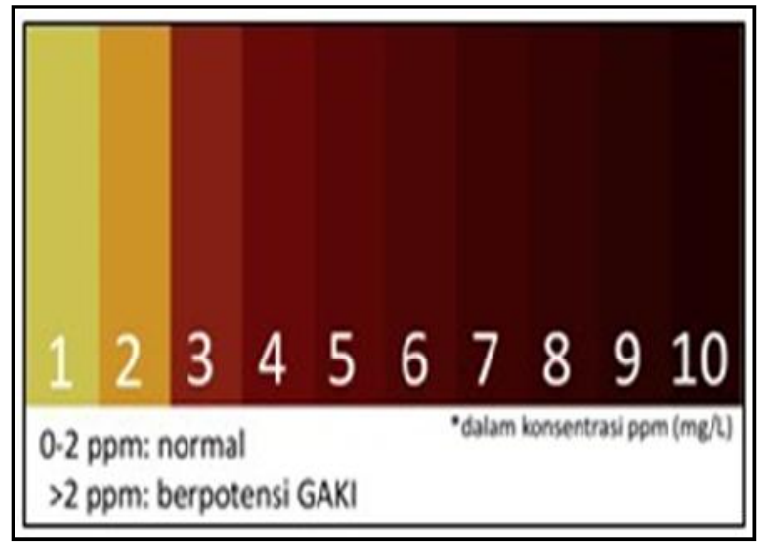

Gambar 6. Komparator Warna Test Kit Tiosianat

Tes kit yang diperoleh selanjutnya divalidasi dengan membandingkan hasil analisis pada sampel sintetis dan urin dengan hasil menggunakan metode standar spektrofotometri melalui pembentukan kompleks $\mathrm{Fe}(\mathrm{SCN})^{2+}$. Hasil validasi menunjukkan bahwa test kit yang dibuat menunjukkan hasil yang berdekatan dengan hasil yang diperoleh dari metode standar spektrofotometri, seperti yang tercantum pada Tabel 1.

Tabel 1. Hasil Validasi Test Kit dengan Metode Standar

\begin{tabular}{ccc}
\hline Konsentrasi & \multicolumn{2}{c}{ Konsentrasi terukur (mg/L) } \\
\cline { 2 - 3 } Sampel (mg/L) & Spektrofotometri & Test kit \\
\hline 0,9 & 0,93 & 1 \\
\hline
\end{tabular}

Selanjutnya dilakukan pengukuran absorbansi dari sampel yang telah diketahui konsentrasinya. Sampel tersebut diukur dengan metode spektrofotometri melalui pembentukan $\mathrm{Fe}(\mathrm{SCN})^{2+}$ dan diperoleh hasil $0,93 \mathrm{mg} / \mathrm{L}$. Hasil pengukuran dengan metode test kit menunjukkan bahwa konsentrasi sampel adalah 1 ppm. Hasil dari penentuan konsentrasi sampel dengan metode tes kit tidak jauh berbeda dengan metode standar analisis tiosianat.

\section{KESIMPULAN}

Analisis tiosianat dapat dilakukan dengan metode tes kit yang didasarkan pada pembentukan kompleks merah hidrindantin. Kompleks hidrindantin terbentuk dari reaksi antara sianida hasil oksidasi tiosianat oleh natrium hipoklorit dengan ninhidrin. Kondisi optimum dari pembentukan kompleks hidrindantin adalah pada $\mathrm{pH} 10$, dengan waktu kestabilan kompleks 15 menit, dan konsentrasi natrium hipoklorit 0,05 M. Test kit yang dihasilkan berisi reagen $\mathrm{Na}_{2} \mathrm{CO}_{3}$ 
$0,5 \%$, ninhidrin $1 \%, \mathrm{NaOCl} 0,5 \mathrm{M} \mathrm{NaOH} 0,5$

$\mathrm{M}$ dan dapat digunakan untuk menganalisis

tiosianat dengan konsentrasi 1-10 ppm yang

didasarkan pada perbedaan intensitas warna kompleks hidrindantin yang dihasilkan. Dari hasil validasi dengan metode standar analisis tiosianat menunjukkan bahwa hasil analisis dengan metode test kit tidak jauh berbeda dengan metode standar.

\section{DAFTAR PUSTAKA}

A'yuni, Q. 2012, Pengaruh Ion Asing dan Uji Validasi Metode Teknik Injeksi Alir-Spektrofotometri Lembayung Ultra pada Penentuan Tiosianat. Skripsi. Fakultas MIPA Universitas Brawijaya, Malang.

Lubis, Z. dan Jumirah. 2013. Analisis Kandungan Tiosianat (SCN-) pada Singkong, Kol dan Daun Singkong. Info Kesehatan Masyarakat, Vol. IX, No. 2, Oktober 2005, 97-100.

Mihaescu, I.M. 2010. Cyanide Determination with A Modified Ninhydrin Reagent
Using N-Acetyl Cysteine in The Presence of Heavy Metal Ions, J. Chil. Chem. Soc., 4, 55, 467-468.

Nagaraja, P., Kumar, M.S.H, Yathirajan, H.S., Prakash, J.S. 2002. Novel Sensitive Spectrophotometric Method for the Trace Determination of Cyanide in Industrial Effluent. Analytical Sciences, 18, 1027-1030.

Putnam, F.D. 1971. Composition and Concentrative Properties of Human Urine. Nasa Contractor Report. http:// http://ntrs.nasa.gov/archive/nasa/casi. ntrs.nasa.gov/.

Sartini, D.N. 2012. Hubungan Antara Ekskresi Iodium Urine dan Ekskresi Tiosianat Urine dengan Total Goiter Rate. Skripsi. Fakultas Kedokteran Universitas Diponegoro, Semarang.

Sulistyarti, H., Spas, D.K., Stephanie L. 2010. Development of Flow Injection Method for Online Determination of Thiocyanate Based on Oxidation by Permanganate, Indo. J. Chem., 10, 2 , $167-171$. 